\title{
Critical Review: Assessing and Seeking the Intricacy or Discrepancy of Ulrich Model Transforming Paradigm in Organization Human Resource
}

\author{
Nor Shela Saleh \\ Faculty of Management, Universiti Teknologi Malaysia \\ shela_saleh87@yahoo.com.my \\ Hashim Fauzy Yaacob \\ Faculty of Management, Universiti Teknologi Malaysia \\ shela_saleh87@yahoo.com.my \\ Mohd Shafie bin Rosli \\ Faculty of Education, Universiti Teknologi Malaysia
}

Doi:10.5901/mjss.2015.v6n2p324

\section{Abstract}

Human Resource (HR) transformation need to enlargement the influence in an organisation. Nonetheless, regard the admonition; change determinations that focus completely on improving human resource (HR) are bounce to fail. Dave Ulrich is the human resource founder and has qualified with evolving the human resource business mate, model and other dominant ideas in books including "HR Champions" and "The HR Value Proposition". Besides, Ulrich explains the six competencies HR be required to develop to accept the challenges of the worldwide economic crisis, globalisation, technological innovations and other change. His argument about Human resources rises to the people employed by an organization. Quantity the value of human resources verifies difficult due to lack of standard and traditional measures such as those related with permanent and liquid assets. For example, human resource cannot depreciate like physical resources, nor do they reflect the net value of an organization as financial resources accomplish. Human resources are just as important as physical and financial resources. Regrettably, organizational leaders and managers frequently overlook this actuality since human resources not used to reflect the organisation's achievement.

Keywords: Human Resource (HR), Transformation, Ulrich Model, Human Resource Value, Human Resource Champions.

\section{Introduction}

It is frequently informal to appear back anything has been than advancing to be. Human Resource (HR) has a prosperous history, but an even more electrifying future. In the past half-century or so, the HR profession has been through three general emission (see figure 1) and a fourth is emerging. All tendencies follow an analogous curve through time with start-up, knowledge, growth, and then immovability. Trend one emphasised the administrative work of HR, somewhere HR personnel focused on rapports and circumstances of work, delivery of HR amenities and regulatory accomplishment. HR was predominantly anything we would illustrate as an "administrative and transactional utility" (Tennat \& Yi-Chien, 2005). Movement one HR roles tend to be filled with people who did an excellent job of management. The transaction and administrative work of HR continue today, but it is comprehensive differently through outsourcing and technology resolutions.

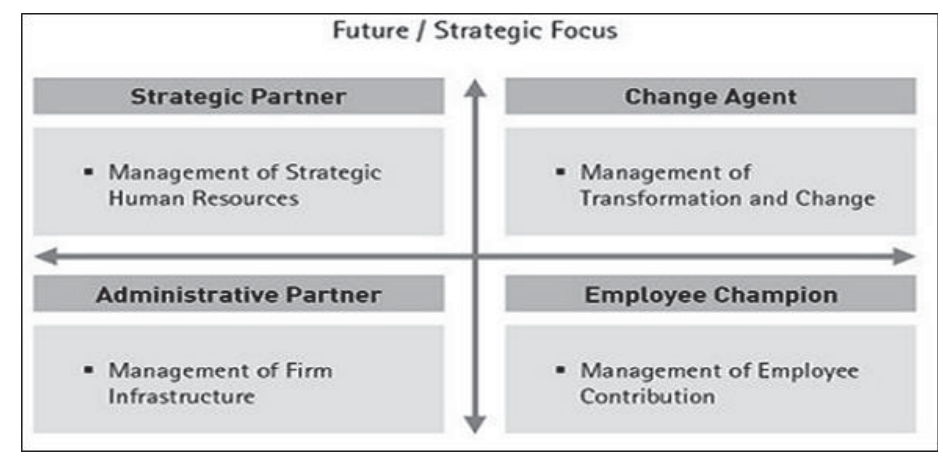

Figure 1: Ulrich Model Strategic Focus and Operational Focus 


\section{Research Objective}

i. To review the role of human resource in Ulrich model implementation.

ii. To explore the research gap in Ulrich model as an evolution model for principle in human resource application.

iii. To connect the Ulrich Model with others model and theory as an intervention participants.

iv. To explore the important and functioning of Ulrich model in organisation.

\section{Research Design}

This research is approximately the critical thinking and assessment the Ulrich Model implementation in human resource specifically in organization process. The method was practice in this research is review and critique. Purposely, the method has been select because to review the importance, the unique in Ulrich Model and to attach that model with others issues. Amongst the top issues is about the management, supervision, leadership, the economic planning and numerous more have been listed in this research argument. Even though, this research sounds as a simple research but compact and compress with all argument and theory or model intervention. Besides, the currently trend of human resource management or planning manner also listed and discuss in this research.

\section{Historical Background}

\subsection{Role of Human Resource in Ulrich Model}

David Ulrich is defined the record collective HR Roles model, which usually used on the market in an organization. The model rationale is for introducing principally the characteristics of human resources with the highest value added. The foremost contribution of the David Ulrich's HR Model was the start of the commission from the purposeful HR orientation to the more company organization in HRM function. Business associate is not possible to contrivance without a major interchange in the HR organization. The benefit was a further accountable and flexible organization of human resources, which adequate to a variety of HR professionals to become actually valued business associates (Ursula, 2005; Kiran \& Clare, 2011).

According to Paul, Wight and Chris (2010), Ulrich contributions and incline of items that evidently expressions four key roles human resources professionals must fulfilled in order to add the uppermost value to the organization. HR professionals need prominence on equally the strategic and the operational, both long-term and short-term. Activities variety from managing processes to supervision people. Based on table 1 shown that the four human resource role in Ulrich model.

Table 1: Role Human Resource in Ulrich Model

\begin{tabular}{|c|c|}
\hline Strategic Partner & Change Champion \\
\hline Employee Champion & Administrative Expert \\
\hline
\end{tabular}

Based on above table 1, shown that four human resource role in Ulrich model and as well talented positioning by line manager in organization for advance personal employee. Table 1 also has correlation with Figure 1 concerning the explanation role HR in Ulrich model in an organization. Henceforth, revolving traditional thinking about HR management advantage down, Dave Ulrich challenge HR professionals to characterize the value they produce for workers to client. Providing capital similarly concentration on the outcomes and results of human resources work.

\section{Conceptual of Ulrich Model Evolution}

Ulrich proceedings that the phase of transformation prerequisite by technology, globalization, profitable growth, and customer demands places supervise proficiency and organizational capabilities at middle phase (John, Aaron \& Nate, 2011). Organizational capabilities are things an organization does expand than its competition, a basis of competitive benefit (such as reorganization order-to-remittance process, learning more speedily than competitors, organizing around customer provisions). He encounters readers to redefine organizational capabilities to endure and integrate individual capabilities. He continues that HR professionals need to localize anything they do in terms of the organizational capabilities they inevitability products. 


\subsection{Business Success through Strategic Human Resource}

Refer on Figure 2, evolution on HR works in movement three has focused on the linking of individual and incorporated $\mathrm{HR}$ practice to corporate accomplishment through planned HR. For the previous 15 to 20 years, HR has functioned to association its work to the approach or persistence of a corporate. This work has elongated HR performs from a primary attention on aptitude to contain involvement on philosophy and leadership. Specified a business's plan, HR professionals would be stimulating with assessing talent, culture, and leadership to appreciate the policy (Ursula, 2005). In this tendency, Tennat (2005) also said the HR professionals twisted strategies into HR significances to distribute on premeditated capacities. The worldwide economic crisis, globalization, technological revolutions, and other modifications in contemporary years have challenged the upcoming of HR (Anne, 2011). A few HR leaders poverty to seem back and reinforce HR administrative effort by doing fundamentals well and others want to return. There are concentrating on embattled HR applies. I would slightly expression forward to an innovative standard for HR (Jonn, Aeren \& Nate, 2011).

Figure 2. Evolutions on HR Work in Waves

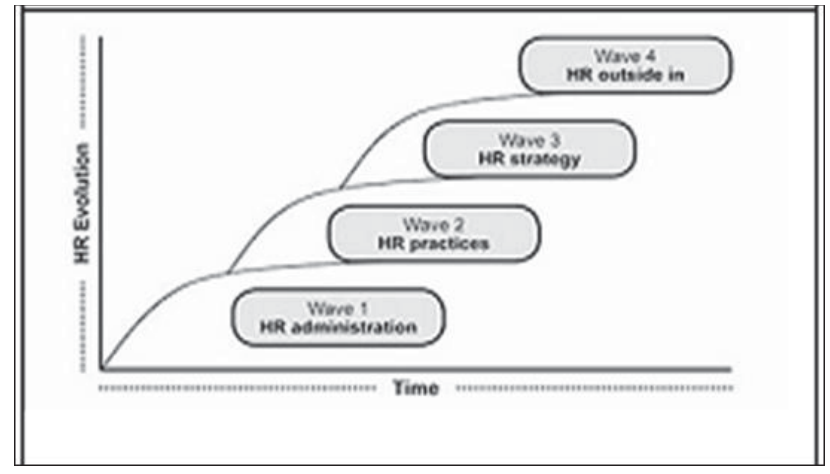

\subsection{Human Resource since the Outside in}

Wave four uses HR performs to instigate and answer to external commercial condition, called "HR from the outside in". Outside-in HR goes beyond strategy to make parallel its work with business perspective and shareholders. The three previous waves characterize HR work that immobile has to be done well. HR administration must be faultless, HR practices must be innovative and incorporated and HR must revolve strategic aspiration into HR performance. According to Neda, Amer and Zahra (2008), these abilities are grounded on research from further than 20,000 respondents around the world. These 20,000 respondents completed valuations of HR competence on 140 behavioural and knowledge substances. These six competencies are credible activist, strategic positional, capability builder, change champion, human resource innovator and integrator and technology proponent (Peng and Carl, 1999).

a. Credible Activist: Probable advanced HR professionals in high-performing companies function by way of reliable innovative. They organise anything about they will do. Such results-based reliability obliges as the foundation of personal expectation that, in opportunity, interprets into professional credibility (Triant \& Ayse, 2010). They have actual interpersonal skills. They transform this positive chemistry into influence that contributes to commercial results (Ronald, 2004). They take resilient positions about business issues that are stranded in complete data and solicitous opinion.

b. Strategic Positional: According to Anthony and Corol (2011), high-performing HR professionals comprehend the global business context-the social, political, economic, ecological, technological, and demographic inclination that allow on their business - besides deduce these inclinations into business insinuations. They appreciate the structure and decision of their own industries and the fundamental competitive dynamics of the marketplaces they supply, including customer, competitor, and supplier trends. Besides, they contribute in increasing customer focused business policies and in transforming the business approach into yearly business strategies and objectives (Indrit \& Sally, 2011).

c. Proficiency Builder: At the organisational level, an effective HR professional creates, audits, and orchestrates an effective and well-built organisation by helping characterize. Capability represents what the organisation is respectable at and acknowledged for (Kiran and Clare, 2011). These capabilities outlast the behaviour or performance of any individual manager or system. Such capabilities capacity comprises innovation, speed, customer focal point, efficiency, and the creation of significance and purpose at work (Paul, 2003). 
d. Revolution Champion: Professionals build up their organisations capability for transformation and explain that ability into effective modification processes. They verify a seamless combination of change processes that constructs sustainable competitive advantage. They physique the occasion for change established on market and commercial representativeness, and overcome resistance to change by engaging significant stakeholders in key decision and construction their commitment to complete implementation. They retain going change by confirming the accessibility of necessary resources including time, people, capital, and information.

e. Technology Proponent: For many years, HR professionals have applied technology to fundamental HR work. HR information systems (HRIS) have been applied to add to the efficiency of HR processes including repayment, payroll processing, health care funding, record keeping, and other administrative services (Peng \& David, 1998). In this HRIS round, we see an affected modification in the insinuations of technology for HR professionals. At the organisation level, high-performing HR professionals are currently convoluted in two additional categories of technological application (Peng \& Carl, 1999). First, HR professionals are applying social networking technology to help people stay connected with each other. They help guide the connectedness of people within the firm and the connectedness between people outside firms (in particular customers) with employees within the firm. Second, in the high-performing firms, HR professionals are increasing their role in the management of information (Stephen, 2002).

\section{Human Resource Roles in Ulrich Model}

\subsection{Deployment to Line Managers}

Currently, we can see that all organizations, regardless of their focus and purpose in an organization. Each of an organization has their own purpose in terms of a goal or set goals optimisms an organization to achieve. Besides that, all organization too poverties mature a systematic arrangement to actuality success organization in the future. Line manager is imperative line in an organization to benefit organization achieved goal and extra productivity in long-term phase. Line manager empower elucidate a group people responsible for establishing an organization complete objective and developing the policies to accomplish objectives. For the successful, line manager necessary deployment human resource roles through Ulrich model (Anthony \& Corol, 2011).

The several part of human resource in Ulrich model is significantly functioning in organization activities and employed. Ulrich Model used by line managers to improve employee personal development in an organization. Consequently, according to Mohsen and Gleen (1999), line manager's obligation more appreciates and closely with employee for empathetic and sympathetic the employee level of competencies at workplace such as performance in production line.

Previously, an explanation from Thomas (1998), regarding human resource role in Ulrich model need be perfect before transmit it with line manager deployment. There are four are indicated role human resource in Ulrich model. First, strategic partner is aligning HR and business strategy such as organizational identification. Second, administrative expert is reengineering organization processes such as collective services. Third, employee champion is process to attending and contribute responding to employees such as providing resources to employees. Last, change agent is managing transformation and change such as for confirming capacity for transformation.

Line manager is more closely with employee and more know an employee level of competencies during working at workplace (Ronald, 2004). Line manager can choose the selecting for training and type of training by observation and performance by employee during working. If selecting will doing by HR, the impossibility chance to bias with employee is highest. It is because HR just picks employee as randomly without see the level of competencies during working. In small companies, training normally is responsibility of founder and all the employees (Jian, 2011). For increase individual development, training should be becomes one of the responsibilities of the employee in charge of human resource. Training can improve job performance because train employees improve their knowledge, ability and skill.

\subsection{Strategic Plan}

Strategic partner role is extra reflecting to human resource department (Mohsen, 2000; Anne, 2011). Line manager also talented deploy this role for development employee continuously. Self-development for employee is precise significant in workplace activity. In strategic partner, human resource confirms that goal and organization role is comparable with employee goal and objective. Consequently, HR role must support with business strategy such as if organization business is connected with technology approach so HR also practical technology in their function (John, Aaron \& Nate, 
2011). At the same time, line manager also can organise this role whereby line manager try to competition their role with organization purpose. Line manager should be creating innovation and transformation for organization planning in the future. That is for ensure that organization business in good level and security. Planning is a very imperative for advance employee development.

\subsection{Providing Resources}

Occasionally, line managers are added appropriate to be change agent for change activities in the change effort expanse and ensuring the capacity for the changes (Kiran \& Clare, 2011; Paul, 2003; Tennat \& Ye-Chiew, 2003). On occasion, line managers can be a change agent. It is because line managers more appreciate the employee required. At times, people equipped for change and sometimes they not set for transformation. For example, some employee habitually suspicions several change that may reduction their job security or proceeds. New laboursaving equipment, for example perhaps inferred as the indication of dismissals. People are also often exposed by changes in job tasks or established work procedures if they anxiety that they determination not be able to achieve the successfully (Ursula, 2005). This is chiefly treating where reimbursement strictly tied to productivity.

\subsection{Develop Change Process and Transformation}

According to Peng and Carl (1999), for be successfully, line managers must know the capacity for change and also attempt to solve employee problem for change. There many way for implement change in an organization such as line managers should be build trust for employee, make open and two way communication for get employee involvement in changing process and line managers try to provide incentives for make change process successful. If employee trust and confidence in change process, they will be, receiving changes propose by line managers. For build trust, may be line managers communicating with employees to help them see the logic of a change (Razvi \& Nevin, 2008).

The most important, change process must be clears and also can make employee better than before. Other element in change is transformation. Transformation is related and synonym with innovation process. Innovation for transformation should be creative. Innovation is a process of turning a creativity idea into a useful product, service, or method of operation. Line managers should know the level of ability employee for received some transformation and innovation (Kolb, 1976; Neda, Amer \& Zahra, 2008). For example, if organization make some innovation in job process whereby before that just doing work manually and when transformation enter in an organization, all employee should be use machine because is more better and can do work more easy and faster than before. Line manager should be providing training for employee learns new method so that employee can improve their knowledge and skill through technology and innovation by transformation.

For change, line manager can apply Lewin Change Model. This model like below Figure 3.

Figure 3. Lewin Change Model

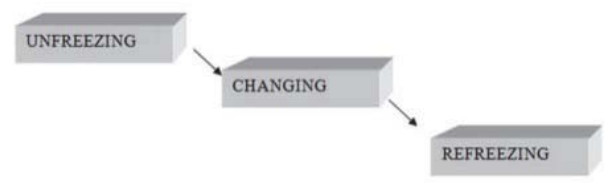

\subsection{Line Managers as Change Agent}

Line managers can use Ulrich model for be a change agent before that, the role of HR in Ulrich model is support for changes activities. Therefore, line managers also can be support for change activities such as make open channel in communication. For example, allow employee to give any idea and information for logic activities in change process. Besides that, employee and line managers can share knowledge and improve employee communication at workplace (Ursula, 2005). Employee will feel that they also useful and have an important part in organization. Employee communication also improves from time to time so that can more talkative and participate in all change process in an organization (Anne, 2011).

\subsection{An Innovation}

Even though revolution and innovation in transformation have advantages, but also negative impact occurs. Changes in organization policies and practice may threaten the expertise of specialized groups and departments (Triant \& Ayse, 
2010).For example, the introduction personal computers, which give supervisors access to information directly from other departments. Computer is a part innovation for make people can interaction among each other easily and costly (Anthony \& Corol, 2011). For solve this problem happen, employee should know how to manage change process in order to change process give more advantages than disadvantages.

\subsection{Employee Necessary}

Line managers can deployment employee champion also a part in HR role in Ulrich model (Indrit, Care \& Sally, 2011). Personal development employee enable improve through training, individual development, career development and motivating employee. Training can improve employee KSA (knowledge, skill and attitudes). Employee champion is line managers providing resources for employee (Thomas, 1998). In training, if organization is installing computer-based manufacturing equipment in one of its plants, there are three strategies organization should be dealing to have computerliterate employees (Tennat, Ye-Chiew, 2005). First, organizations decide that, given its staff expertise and resources, it can use internal consultants to train all employees. Second, organization decide identify employees who are computer liberate by using tests and work samples. Third, if lacks time, organization may decide to purchase training a consultant. It is because for advance employee performance at workplace.

\subsection{Individual Development}

Encouragement employee performance applies by continuous employee development, individual development and career development important (Jeaneette, 2005). Organization should be providing a resource for employee in continue development as either individual development or career development. Employee and line managers can together as a team to guarantee career development (Jian, 2011). Career development may help employee analyse their abilities and interest to better match employee for development. Career development involve learning, training for develop knowledge and skill (Stephen, 2002). Line managers should know several guidelines for line managers to make career development. The first step must start small and design a specific program in response to a particular need, and integrate the program into on-going personal activities or programs. Besides that, also encourage time management and lobby for support. Lastly, develop an evaluation process and communicate measured results for continue to explore alternatives and maintain flexibility (Jian, 2011; Kolb, 1984; Kolb, 1976; Kolb \& Fry, 1975). This part we can apply Kolb Learning Cycle theory because this theory by David Kolb (1984) is theory four sets out four distinct learning styles. This theory is for learning and development process without beginning and stopping.

\subsection{Mentoring System}

Second are developing mentoring systems. Mentoring systems help explain the confusing probability of the organization, provide objective assessment of the strengths and weaknesses. Mentors can develop employee talents and skills in human relations, and higher management can perceive which employee have the ability to develop within the organization (Ronald, 2004). Additionally, mentoring functions purpose to instil additional reliability and commitment to the line managers to the organization on the slice of both the mentor and the employee.

\subsection{Reengineering Process}

Line managers should be confirming administrative in an organization has possible quality (Paul, Wright \& Chris, 2010). Administrative expert is a part HR role in Ulrich model. Reengineering process is involved in administrative expert function. Reengineering process related with organization development activities. Line managers possibly will advantage HR role to improve employee personal development (Peng, 1999). Reengineering process also relate with effective control by organization. There are several effective controls for administrative expert to being successfully in reengineering process. Charles Tenant and Yi Chien Wu (2005) mention that to identify factors for being success of business process reengineering in UK companies must use several way and method. For deployment line managers can identify in deep trouble and find solution to further implementation. Furthermore, reengineering process can motivate employee .It is because employee will work with new system, new method or new environment such as technology (Mohsen, 2000).

\subsection{Training and Learning Program}

Training program is part activity to develop knowledge, ability and skill among employee at workplace (Kolb, 1984; Neda, 
Aamer \& Zahra, 2008). Line manager should understand the most important and best training program for develop employee skill because they most know level of skill and knowledge of employee based on employee necessary. Training can change employee attitude and knowledge (Kolb \& Fry, 1975). The best-training program are when employee came back at workplace, they can transfer all the input and knowledge in training program at workplace so that their performance more increase and satisfied by organization.

Learning process is a change human capability to achieve specific learning outcomes (Kolb, 1984; John, Aaron \& Nate, 2011). Line managers also identify learning outcome can develop employee personal development such as intellectual skill, motor skill, attitudes and cognitive strategies. Based on table 2 shown that learning outcomes to develop employee personal development.

Table 2: Capabilities for Learning Outcomes

\begin{tabular}{|l|l|}
\hline Type of learning Outcomes & Description of capabilities \\
\hline Intellectual Skill & Apply simplify ideas and rules to resolve problems \\
\hline Motor Skill & Accomplish a physical action with accuracy and timing \\
\hline Attitudes & Choose a personal way of action \\
\hline Cognitive Strategies & Manage own rational and learning developments \\
\hline
\end{tabular}



Figure 4: Kolb Learning Cycle

In place of the successful learning theory should be use continues learning theory so that may improve their performance at workplace from time to time. For continues learning can use Kolb Learning Cycle (1984) for successful learning at among employee. In this theory very suitable with employee development because in that theory Kolb mentions to these four phases as, concentrate experience, reflective observation, abstract conceptualization and active experiment. All four phases always encourage employee learn and try to improve their own self to have successfully at workplace (Kolb \& Fry, 1975; Kolb, 1884). Based on figure 4 shown that how Kolb Learning Cycle applied in learning among employee by line manager to development personal development.

\section{Expectation in Outcome}

\subsection{The Important Line Manager Deployment Human Resource Role in Ulrich Model}

If HR teams are to realise their potential and be true partners to the business, then they need to let go a little more and expectation their managers with the day-today matter (Anne, 2011). This doesn't mean actuality unsupportive or resigning responsibility for the method that people are achieved. It does mean important approaches and policies and then placing in place the frameworks and the structures that allow managers to take responsibility for the day-to-day performance but in an organized, informed and operative way. In an organization, human potential can be develop of manager always perform to develop employee performance at workplace. Also, maintaining employee successfully in an organization can reduce cost because old employee those have high performance can maintain as performer in the future.

Besides that, Just wanting that line managers would take more accountability and HR professionals could be new strategic is not working to make it so, of course. Well solutions are wanted to maintenance key people managing processes and it's likely that able use of technology is prospective to signify at least part of the answer. When employee able uses technology at work place, they can improve themselves and can encourage performance. There are many type of technology use at workplace such as computer based training. Computer based training (CBT) a new approach by certain company like big company to make their job easier and simplified. Application on CBT perhaps organization 
achieve more than before (Anthony \& Corol, 2011).

Technology-based facilities compromise organisations the possible to give much better maintenance to their line managers, but in an extremely cost-effective method (Indrit, Care \& Sally, 2011). Line managers can be given implements to walk them through communal processes, access to inclusive information about their employees, regulation on how to manage effectively, and prompts when tasks or movements are due - all retrieved via a single web-based service. The benefit for HR is that the line managers can be more authorized and more self-sufficient, while the HR team recalls control over the procedures and the strategies and has full perceptibility over how managers are handling.

\subsection{Human Resource Function is redesigned}

Our point is that HR professionals often focus internally on their own function and roles. We believe that the biggest challenge they face today is helping their organizations accomplish something. That's not to say that activities such as hire people and developing leaders for building incentive programs do not matter (John, Aaron \& Nate, 2011). However, our quarrel is that HR professionals should be at smallest as worried with the products of these happenings. Each people in organization have their own position and significance to help organization achieve something. The contribution by employee suitable with employee called as 'human capital'. Here, capital not only refers to money or some investment about money but through employee also can call it as capital. Knowledge, skill and attitude are the main point to achieve more capital by employee (Jian, 2011). Listed can be define employee as capital when the have enrichment of knowledge, highest of skill and kind of attitude by employee meaning that the employee perfect.

\section{Conclusion and Suggestion}

The role in Ulrich model is not always for HR but today also can be applied by line managers for development employee continues personal development. Although HR functions similar leading HR function but line managers also may deploy HR role. There are several advantages such as line manager can know what are trendy and enable concentration on the employee job. Here, some suggestion are HR and line manager cooperation to association Ulrich model implement together to ensure employee personal development successfully in the future. Line manager and HR can produce activities for employee and working together for effectiveness collaboration amongst HR and line managers. Therefore, $\mathrm{HR}$ and line managers added professional, specialists and experts in their fields and employee more knowledgeable at workplace.

\section{References}

Anne, G. C. (2011). Does OD Practice Within the Human Resource Profession in the UK Reflect the Academic Rhetoric? Leadership and Organization Development Journal, 2, 150-169.

Anthony, M. \& Corol, G. (2011). The Point of Partnership: The Case for Employee Engangment in Education. Emerald Group Publishing Limited of Journal, 1, 21-27.

Indrit, T., Care, J. \& Sally, R. (2011). Exploring the Public Sector Adoption of HRIS. Industrial Management and Data Systems, 3, 470488.

Jeaneette, L. (2008). From Administrative Expert to Strategic Partner. Employee Human Relation Journal, 2, 182-196.

Jian Wang (2011). Understanding Managerial Effectiveness: A Chinese Perspective. Journal of European Industrial Training, 1, 6-23.

Jon, Y., Aaron, Y. \& Nate. T. (2011). Developing the Skills of Human Resource: Business Partnership. Consulting and Change Management of Journal, 1, 6-14.

Kiran, T. \& Clare, R. (2011). Theorising Critical Human Resource Development: A Paradox of Intricacy and Discrepancy. Journal of European Industrial Training, 3, 276-290.

Kolb, D. A. \& Fry, R. (1975). Toward An Applied Theory of Experiential Learning. London: John Wiley.

Kolb, D. A. (1976). Management and the Learning Process. California: (pp: 21-31).

Management Review.

Kolb, D. A. (1984). Experiential Learning : Experiences As a Source of Learning and Development. New Jersey : Prentice Hall.

Mohsen, A. (2000). Why Does Reengineering Fail? A Practical Guide for Successful Implementation . Journal a Management Development, 9, 794-801.

Mohsen, A. \& Glenn, G. W. (1999). How to Succeed at Reengineering. London: Kogan Page Ltd.

Neda, A., Amir, A. \& Zahra, F. (2008). Assessing Readiness for Business Process Reengineering. Business Process Management Journal, 4, 497-511.

Paul, B. (2003). Seeking Success through Strategic Management Development. Journal European Industrial Training, 3, 292-303.

Paul, J. G., Wight, W. \& Chris, B. (2010). Human Resource on the Line: The Role of Human Resource Professionals and Line 
Management in the Modern Organisation. London: Tavistock.

Peng, S. C. \& Carl, L. (1999). Implementing Reengineering Using Information Technology. Business Process Management Journal, 4 , 311-324.

Peng, S. C. \& David, P. (1998). Causes and Impact of Reengineering. Business Process Management of Journal, 1, 44-55.

Razvi, D. \& Nevin, V. J. (2008). Business Process Modelling, Simulation and Reengineering: Call Centress. Business Process Management Journal, 6, 838-848.

Ronald, J. B. (2004). Process Reengineering : Who Embraces it and Why? Emerald Group Publishing Limited of Journal, 2, $114-119$.

Stephen, T. T. (2002). Effectivenss of A Corporate Human Resource Department in a Australian Public Sector Entity During Commercialization and Corporation. The International Journal of Human Resource Management, 7, 89-105.

Tennat, T. \& Yi-Chien, W. (2005). The Application of Business Process Reengineering in the UK. Emerald Group Publishing Limited of Journal, 6, 537-545.

Thomas, F. B. (1998). Modelling the Impact of Reengineering with System Dynamics. International Journal of Operations and Production Management, 9, 950-963.

Triant, F. \& Ayse, K. Y. (2010). The Risk Management Framework to Strategic Human Resource Management. Research Journal of Finance and Economics, 6, 67-72.

Ursula, F. (2005). Human Resource as a Strategic Partner: Culture Change as an American Express Case Study. Human Resource Management Journal, 1, 79-84. 